\title{
Hubungan antara Aktivitas Fisik Terhadap Memori Kerja Murid SMA Don Bosco III Bekasi
}

Michelle Clarissa Junaidi, Bertha Soegiarto

Fakultas Kedokteran Unika Atma Jaya Jakarta

Latar belakang. Memori kerja merupakan bagian dari memori jangka pendek yang berperan penting dalam membantu proses pembelajaran dan dipengaruhi oleh aktivitas fisik, memori kerja yang rendah akan menimbulkan kesulitan untuk menerima informasi baru serta penurunan prestasi belajar.

Tujuan. Mengetahui pengaruh aktivitas fisik terhadap kapasitas memori kerja murid SMA Don Bosco III.

Metode. Penelitian metode analitik dengan pendekatan potong lintang pada 113 murid SMA Don Bosco III, Bekasi, pada 18 - 20 Juli 2016. Penelitian dilakukan dengan menggunakan kuesioner demografi, kuesioner skrining gangguan mental dan penyakit kronis, Physical Acitivity Questionnaire of Adolescent (PAQ-A) dan Operation Span (O-SPAN). Analisis data dengan univariat dan bivariat menggunakan uji korelasi Spearman.

Hasil. Terdapat 113 murid SMA Don Bosco III dengan kisaran usia 14 - 17 tahun, usia terbanyak 15 tahun (47.8\%), laki-laki 61,1\%, murid kelas X 44.2\%. Mayoritas responden memiliki aktivitas fisik "kurang baik" dan rerata memori kerja 6,16. Analisis Spearman menunjukkan terdapat hubungan bermakna $(\mathrm{p}<0,05)$ antara aktivitas fisik terhadap memori kerja dengan korelasi positif lemah $(r=0,384)$.

Kesimpulan. Terdapat korelasi positif antara aktivitas fisik dan memori kerja, aktivitas fisik yang semakin tinggi cenderung akan meningkatkan memori kerja. Sari Pediatri 2016;18(4):251-9

Kata kunci: aktivitas fisik, memori kerja, murid SMA.

\section{The Relation of Physical Activity and Working Memory in Don Bosco III Senior High Students Bekasi}

Michelle Clarissa Junaidi, Bertha Soegiarto

Background. Working memory is a part of short term memory to help learning processes which affected by physical activity. Low working memory cause difficulty in processing new information and decreasing learning achievements.

Objectives. To determine the relationship of physical activity and working memory in Don Bosco III senior high school students. Methods. This research was done cross-sectionally using analitic methods to 113 Don Bosco III senior high students, Bekasi, on $18^{\text {th }}-20^{\text {th }}$ July 2016. This research used demographic questionnaire, mental disturbance and chronic disease screening questionnaire, Physical Acitivity Questionnaire of Adolescent (PAQ-A) and Operation Span (O-SPAN). Data analysis using univariate and bivariate test with Spearman correlation test.

Results. There were 113 of Don Bosco III senior high students ranging from 14 to 17 years old, with majority of 15 years old (44.2\%) , $61.1 \%$ male, $44.2 \% 10^{\text {th }}$ grade students. Majority of students had a "quite low" physical activity and mean of working memory score was 16,16 . Spearman analysis showed significant association between physical activity and working memory with positive correlation. Conclusion. There was positive correlation between physical activity and working memory, higher physical activity would increase working memory. Sari Pediatri 2016;18(4):251-9

Keywords: physical activity, working memory, senior high school students.

Alamat korespondensi: Dr. Michelle Clarissa Junaidi. Fakultas Kedokteran Unika Atma Jaya Jakarta. Jl. Pluit Raya Nomor 2, Jakarta 14440. Email: michelleclarissa00@gmail.com 
$\mathrm{R}$ emaja adalah individu dalam kisaran usia 13 - 19 tahun, merupakan masa peralihan dari masa kanak dan masa dewasa. Namun, remaja belum dapat bertanggung jawab layaknya orang dewasa. Perkembangan yang terjadi pada masa remaja adalah aspek kognitif, fisik, dan mental (perilaku, emosi, pola berpikir dan lainnya). Hing ${ }^{1}$ menyatakan bahwa gaya hidup remaja tergantung pada kemajuan teknologi, seperti penggunaan alat elektronik (telepon genggam, komputer, gadget dan lainnya), yang digunakan lebih dari 2 jam per hari. Penggunaan telepon genggam, komputer, konsol game dan alat elektronik lain yang berlebihan dinamakan adiksi internet. Penggunaan yang berlebihan dapat menimbulkan berbagai dampak antara lain fisik, mental dan kognitif. ${ }^{1,2}$

Riset Kesehatan Dasar (Riskesdas) 2013 menunjukkan bahwa tingkat aktivitas fisik penduduk Indonesia rendah, yaitu 26,1\% penduduk Indonesia kurang melakukan aktivitas fisik dan 24,1\% penduduk memiliki pola hidup sedentari (kurang aktif bergerak) 6 jam per hari. ${ }^{3}$ Pusat Pengembangan Kualitas Jasmani Kementrian Pendidikan Nasional tahun 2010 melakukan uji kesegaran jasmani Indonesia pada siswa Sekolah Dasar (SD), Sekolah Menengah Pertama (SMP), Sekolah Menengah Atas (SMA), dan Sekolah Menengah Kejuruan (SMK) pada 12.240 siswa di 17 Provinsi. Hasil uji menunjukkan 17\% siswa dengan tingkat kebugaran baik, 38\% tingkat kebugaran sedang, dan 45\% tingkat kebugaran kurang. Kondisi tersebut dapat menyebabkan risiko daya tahan tubuh kurang, sering absen, prestasi belajar menurun bahkan tidak naik kelas, dan dapat berdampak lanjut kepercayaan diri siswa menurun. ${ }^{4}$ Tingkat aktivitas fisik yang rendah dapat menimbulkan masalah kesehatan, seperti obesitas, hipertensi maupun kondisi prediabetes di usia muda, dan lainnya. ${ }^{5}$

Tingkat aktivitas fisik yang rendah selain menyebabkan masalah kesehatan fisik dan mental juga memengaruhi fungsi kognitif, seperti memori kerja, motivasi belajar, dan konsentrasi. Penelitian Kate $^{6}$ menyatakan bahwa individu dengan aktivitas fisik rendah menyebabkan kemampuan konsentrasi berkurang dan tidak dapat melakukan beberapa tugas secara bersamaan. Memori kerja merupakan bagian dari memori jangka pendek yang berfungsi menyimpan dan memanipulasi informasi sehingga membantu proses pembelajaran, pemahaman dan perilaku seseorang termasuk motivasi mencapai tujuan hidup. ${ }^{7}$ Remaja memiliki memori kerja yang terbaik dibandingkan kelompok usia lain (anak dan dewasa). Memori kerja akan terus meningkat dan mencapai puncaknya pada usia remaja hingga dewasa muda ( $<20$ tahun). ${ }^{8}$ Memori kerja yang rendah menyebabkan murid sulit untuk mengolah materi pelajaran, menerima informasi baru, mengikuti instruksi pembelajaran yang berdampak prestasi belajar menurun. ${ }^{?}$

Berdasarkan kondisi tersebut dan belum banyak penelitian yang dilakukan mengenai aktivitas fisik dan memori kerja pada remaja maka peneliti berminat melakukan penelitian mengenai hubungan aktivitas fisik terhadap memori kerja pada murid Sekolah Menengah Atas.

\section{Metode}

Desain penelitian analitik dengan desain potong lintang digunakan untuk mengetahui hubungan antara aktivitas fisik terhadap memori kerja murid SMA Don Bosco III. Penelitian dilaksanakan dengan membagikan kuesioner PAQ-A untuk mengukur aktivitas fisik, dengan setiap jawaban "A" mendapat nilai 1 dan jawaban "E" mendapat nilai 5, kemudian dihitung rata-rata yang mewakili aktivitas fisik. Rerata PAQ-A 1 sampai 5 menunjukkan aktivitas fisik dari "sangat kurang" sampai "sangat baik". Uji O-SPAN ditujukan untuk mengukur memori kerja yang dilakukan pada masing-masing subyek. Hal ini dilakukan untuk 3 set dengan 3 sub-set. Subset pertama berisi 2 huruf, sub-set kedua berisi 3 huruf dan sub-set ketiga berisi 4 huruf. Responden akan diberikan kartu berisi perhitungan matematika sederhana dan sebuah huruf, kemudian responden diminta untuk membacakan perhitungan matematika tersebut lalu menyatakan "benar" bila perhitungan matematika tersebut tepat dan menyatakan "salah" apabila perhitungan matematika tersebut tidak tepat, kemudian menyebutkan huruf yang tertulis dengan suara lantang dan menghafal huruf tersebut kemudian menyebutkan ulang huruf dalam sub-set yang telah dihafalkan secara urut. Apabila responden salah dalam menyebutkan ulang maka penilaian dihentikan dan akan dilanjutkan ke set selanjutnya. O-SPAN tidak memiliki nilai normal yang pasti, melainkan menggunakan rerata memori kerja dari seluruh subyek yaitu 16,16 sebagai nilai normal pada penelitian ini. Pengukuran menggunakan PAQ-A 
maupun O-SPAN dilakukan setelah pembagian kuesioner skrining dan kuesioner demografi. Tempat penelitian di SMA Don Bosco III, Bekasi. Subjek diambil menggunakan metode total sampling, yaitu mengambil seluruh murid SMA Don Bosco III sebagai subyek penelitian.

\section{Hasil}

Penelitian dilaksanakan pada bulan Februari hingga Oktober 2016, dan pengambilan data pada bulan Juli

Tabel 1. Karakteristik demografi responden

\begin{tabular}{lcc}
\hline Karakteristik & Frekuensi & $\%$ \\
\hline Usia (tahun) & & \\
14 & 14 & 12,4 \\
15 & 54 & $47,8^{*}$ \\
16 & 33 & 29,2 \\
17 & 12 & 10,6 \\
Jenis kelamin & & \\
Laki-laki & 69 & $61,1^{*}$ \\
Perempuan & 44 & 38,9 \\
Kelas & & \\
X & 50 & $44,2^{*}$ \\
XI & 43 & 38,1 \\
XII & 20 & 17,7 \\
\hline
\end{tabular}

*persentase terbanyak
2016 selama 3 hari. Jumlah subyek adalah 211 orang, 8 tidak hadir, 10 menolak, dan 80 tidak memenuhi kriteria inklusi dan eksklusi sehingga didapatkan 113 subyek yang memenuhi kriteria penelitian.

Pada Tabel 1 tertera bahwa mayoritas responden berjenis kelamin laki-laki $(61,1 \%)$ dengan usia terbanyak adalah 15 tahun $(47,8 \%)$ dan tingkat pendidikan terbanyak kelas X $(44,2 \%)$.

Hasil penelitian pada Tabel 2 menunjukkan bahwa secara umum $63,7 \%$ subyek memiliki tingkat aktivitas fisik "kurang baik" (Skor PAQ-A = 2), serta tidak didapatkan subyek dengan aktivitas fisik "baik"

Tabel 2. Karakteristik umum aktivitas fisik dan memori kerja

\begin{tabular}{lcc}
\hline Variabel & \multicolumn{2}{c}{ Jumlah responden } \\
\cline { 2 - 3 } & $\mathrm{N}$ & $\%$ \\
\hline Aktivitas fisik & & \\
Sangat kurang & 14 & 12,4 \\
Kurang baik & $72^{*}$ & $63,7^{*}$ \\
Cukup baik & 27 & 23,9 \\
Baik & 0 & 0 \\
$\quad$ Baik sekali & 0 & 0 \\
Total & 113 & 100 \\
Memori kerja & & \\
Baik $(<16,16)$ & 54 & 47,8 \\
$\quad$ Kurang baik $(\geq 16,16)$ & $59^{*}$ & $52,2^{*}$ \\
Total & 113 & 100 \\
\hline
\end{tabular}

*persentase terbanyak

Tabel 3. Gambaran karakteristik aktivitas fisik dan rerata memori kerja

\begin{tabular}{|c|c|c|c|c|c|}
\hline \multirow[t]{2}{*}{ Demografi } & \multicolumn{3}{|c|}{ Aktivitas fisik } & \multirow{2}{*}{$\begin{array}{c}\text { Rerata } \\
\text { aktivitas Fisik } \\
\text { (Rentang) }\end{array}$} & \multirow{2}{*}{$\begin{array}{l}\text { Rerata memori } \\
\text { kerja (rentang) }\end{array}$} \\
\hline & $\begin{array}{c}\text { Sangat kurang } \\
\mathrm{N}(\%)\end{array}$ & $\begin{array}{c}\text { Kurang baik } \\
\mathrm{N}(\%)\end{array}$ & $\begin{array}{c}\text { Cukup baik } \\
\mathrm{N}(\%)\end{array}$ & & \\
\hline \multicolumn{6}{|l|}{ Usia (tahun) } \\
\hline 14 & $4(3,5)$ & $9(7,9)^{*}$ & $1(0,9)$ & $1,57(1,3-3,1)$ & $14,6(2-27)$ \\
\hline 15 & $4(3,5)$ & $34(30,1)^{*}$ & $16(14,2)$ & $2,22(1,0-3,4)^{*}$ & $15,5(3-27)$ \\
\hline 16 & $4(3,5)$ & $19(16,8)^{*}$ & $10(8,9)$ & $2,18(1,3-3,1)$ & $17,9(4-27)^{*}$ \\
\hline 17 & $2(1,8)$ & $10(8,9)^{*}$ & $0(0)$ & $1,83(1,2-2,3)$ & $16,2(5-27)$ \\
\hline \multicolumn{6}{|l|}{ Jenis kelamin } \\
\hline Laki-Laki & $7(6,2)$ & $40(35,4)^{*}$ & $22(19,5)$ & $2,22(1,0-3,4)^{*}$ & $16,7(2-27)^{*}$ \\
\hline Perempuan & $7(6,2)$ & $32(28,3)^{*}$ & $5(4,4)$ & $1,95(1,2-2,9)$ & $16(3-27)$ \\
\hline \multicolumn{6}{|l|}{ Kelas } \\
\hline $\mathrm{X}$ & $5(4,4)$ & $34(30,1)^{*}$ & $11(9,7)$ & $2,12(1,2-3,2)$ & $14,4(2-27)$ \\
\hline XI & $4(3,5)$ & $24(21,2)^{*}$ & $15(13,3)$ & $2,26(1,0-3,4)^{*}$ & $18,8(4-27)^{*}$ \\
\hline XII & $5(4,4)$ & $14(12,4)^{*}$ & $1(0,9)$ & $1,80(1,2-3,4)$ & $14,7(5-27)$ \\
\hline
\end{tabular}

*persentase terbanyak 
maupun "baik sekali". Memori kerja kurang baik berjumlah lebih banyak dibandingkan memori kerja baik $(52,2 \%$ dan $47,8 \%)$ dengan menggunakan rerata memori kerja keseluruhan sebagai nilai normal memori kerja.

Tabel 3 menunjukkan rerata aktivitas fisik paling baik. Didapatkan pada usia 15 tahun $(2,22)$, jenis kelamin laki-laki $(2,22)$ dengan tingkat pendidikan kelas XI $(17,9)$. Rerata memori kerja paling baik terdapat pada golongan subyek berusia 16 tahun $(17,9)$, jenis kelamin laki-laki $(16,7)$ dan tingkat pendidikan kelas XI $(18,8)$.

Responden dengan tingkat aktivitas fisik yang semakin baik memperoleh rerata memori kerja yang semakin tinggi pula. Pada responden dengan aktivitas fisik "sangat kurang" didapatkan rerata memori kerja 12,64; pada responden dengan aktivitas fisik "kurang baik" rerata memori kerja 14,93 , sedangkan pada responden dengan aktivitas fisik baik memiliki rerata memori kerja 21,26. Hubungan antara aktivitas fisik terhadap memori kerja menunjukkan bahwa terdapat hubungan yang bermakna $(\mathrm{p}=0,000)$ dengan koefisien korelasi 0,384 yang menunjukkan korelasi positif lemah.

\section{Pembahasan}

Mayoritas responden memiliki tingkat aktivitas fisik "kurang baik", bahkan tidak ada yang memiliki tingkat aktivitas fisik "baik" atau "sangat baik". Hal tersebut sesuai dengan data Riskesdas bahwa mayoritas siswa Indonesia memiliki tingkat aktivitas fisik kurang. ${ }^{4,11}$ Memori kerja diukur menggunakan O-SPAN pada masing-masing subyek. O-SPAN tidak memiliki nilai normal yang pasti, melainkan menggunakan rerata memori kerja dari seluruh subyek yaitu 16,16 sebagai nilai normal pada penelitian ini. Memori kerja "kurang baik" berjumlah lebih banyak dibandingkan memori kerja "baik" (52,2\% dan 47,8\%) dapat disebabkan karena tingkat aktivitas fisik yang rendah secara keseluruhan karena mayoritas memiliki aktivitas fisik "kurang baik". ${ }^{12}$

Rerata aktivitas fisik murid kelas X dan XI lebih baik dibandingkan XII, hal ini sesuai dengan pernyataan Leggett ${ }^{13}$ yang melaporkan bahwa tingkat aktivitas fisik seseorang cenderung berbanding terbalik dengan tingkat pendidikan karena bertambahnya kewajiban sehingga waktu senggang berkurang.
Penurunan aktivitas fisik seiring bertambahnya usia dari usia 15 tahun $(2,22)$ sampai 17 tahun $(1,83)$ sesuai dengan pernyataan Telama. ${ }^{11}$ Namun, aktivitas fisik yang lebih rendah pada golongan usia 14 tahun dapat disebabkan oleh perubahan lingkungan dari SMP menuju SMA serta lingkungan sekolah baru, hal ini termasuk dalam faktor eksternal (teman, dan sekolah) yang dapat memengaruhi aktivitas fisik remaja. ${ }^{11}$ Pada kelompok laki-laki dengan tingkat aktivitas fisik lebih baik dibandingkan perempuan (2,22 dan 1,95), didapatkan memori kerja yang lebih baik pula (16,7 dan 16). Selain itu, terjadi penurunan memori kerja antara kelompok usia 16 dan 17 dikarenakan penurunan aktivitas fisik. Tidak terjadi penurunan memori kerja antara kelompok usia 15 dan 16 dikarenakan penurunan aktivitas fisik tidak signifikan serta memori kerja lebih matang pada usia 16 tahun dibandingkan usia 15 tahun.

Terdapat korelasi positif lemah antara aktivitas fisik terhadap memori kerja. Berbagai penelitian yang mendasari hubungan antara aktivitas fisik terhadap memori kerja sesuai dengan penelitian Carvalho ${ }^{14}$ yang melaporkan bahwa aktivitas fisik meningkatkan kognitif dengan meningkatkan saturasi oksigen serta angiogenesis otak, meningkatkan neurotrofin seperti BDNF (Brain Derived Neurotrphic Factor) yang dapat meningkatkan viabilitas neuron, plastisitas otak serta memperbanyak jumlah sinaps, selain itu jumlah endogenous stem cell pada hipokampus juga bertambah. ${ }^{14}$ Korelasi lemah dapat disebabkan karena pengabaian faktor-faktor yang juga berpengaruh pada memori kerja, seperti waktu tidur dan skrining ADHD serta keterbatasan lain dalam penelitian ini, seperti PAQ-A hanya dapat mengukur frekuensi aktivitas fisik selama 1 minggu terakhir, serta jumlah rangkaian O-SPAN yang terbatas.

\section{Kesimpulan}

Mayoritas tingkat aktivitas fisik responden adalah "kurang baik". Memori kerja kurang baik (52,2\%) lebih banyak dibandingkan memori kerja baik $(47,8 \%)$. Memori kerja paling baik terdapat pada kelompok subyek dengan aktivitas fisik "cukup baik". Terdapat korelasi positif lemah antara aktivitas fisik dengan memori kerja, peningkatan memori kerja seiring dengan meningkatnya aktivitas fisik. 


\section{Daftar pustaka}

1. Ma HK. Internet addiction and antisocial internet behavior of adolescents. Scientific World J 2011;11:2187-96.

2. Babey SH, Hastert TA, Wolstein J. Adolescent sedentary behaviors: correlates differ for television viewing and computer use. J Adolesc Health Publ Soc Adolesc Med 2013;52:70-6.

3. Infodatin Olahraga. [diunduh 23 Maret 2016]. Didapat dari: http://www.depkes.go.id/resources/download/pusdatin/infodatin/ infodatin_olahraga.pdf.

4. Kementrian Kesehatan R. Strategi nasional penerapan pola konsumsi makanan dan aktivitas fisik untuk mencegah penyakit tidak menular. [diunduh 2 Maret 2016]. Didapat dari: http://gizi.depkes.go.id/download/

5. Booth FW, Roberts CK, Laye MJ. Lack of exercise is a major cause of chronic disease. Compr Physiol 2012;2:1143-211 .

6. Lambourne K. The relationship between working memori capacity and physical activity rates in young adults. J Sports Sci Med 2006;5;149-53.

7. D'Esposito M, Postle BR. The cognitive neuroscience of working memory. Annu Rev Psychol 2015;66:115-42.
8. Brockmole JR, Logie RH. Age-related change in visual working memory. a study of 55,753 participants aged 8-75. Front Psychol 2013;4:12.

9. Alloway TP. Working memory, but not IQ, predicts subsequent learning in children with learning difficulties. Eur J Psychol Assess 2009;25:92-8.

10. Luh Anggi Vertikal. Aktivitas fisik, asupan energi, dan asupan lemak hubungannya dengan gizi lebih pada siswa SD Negeri Pondok Cina 1 Depok [Tesis]. Jakarta: Fakultas Psikologi Universitas Indonesia, 2012.

11. Telama R, Yang X. Decline of physical activity from youth to young adulthood in Finland. Med Sci Sports Exerc 2000;1617-22.

12. Wilhelm O, Hildebrandt A, Oberauer K. What is working memory capacity, and how can we measure it? Front Psychol 2013;4:433. doi: 10.3389/fpsyg.2013.00433.

13. Leggett C, Irwin M. Factors associated with physical activity among Canadian high school students. Int J Public Health 2012;57:315-24.

14. Carvalho A, Rea IM, Parimon T, Cusack BJ. Physical activity and cognitive function in individuals over 60 years of age: a systematic review. Clin Interv Aging 2014;9:661-82. 


\section{Lampiran 1}

\section{Operation Span (O-SPAN)}

Nomor Responden:

O-SPAN merupakan alat ukur yang digunakan untuk mengukur kapasitas memori kerja, uji ini tidak bersifat self-report dengan perkiraan waktu pengujian kurang lebih selama 10 menit. Uji ini terdiri dari 1 set uji coba (skor tidak dinilai) dan 3 set uji yang sebenarnya (skor dinilai)

\section{Petunjuk:}

1. Bacalah perhitungan matematika dibawah ini dengan bersuara.

2. Menyebutkan "BENAR" apabila menurut anda perhitungan matematika tersebut benar, dan "SALAH" apabila menurut anda perhitungan matematika tersebut salah.

3. Menyebutkan huruf yang terdapat dibawah ini dan dihafalkan.

4. Mengulang langkah 1 sampai 3.

5. Menyebutkan huruf yang telah dihafalkan saat diminta oleh penguji.

6. Perhitungan matematika tidak boleh salah lebih dari $20 \%$, apabila didapatkan kesalahan lebih dari $20 \%$ maka uji dihentikan.

7. Apabila partisipan salah dalam mengulang huruf yang diminta maka uji dihentikan.

\begin{tabular}{|l|c|c|c|c|}
\hline Set Uji Coba \\
\hline$(9-7) \times 3=6$ & B/S & HURUF & CHECK & TOTAL \\
\hline$(4-2) \times 3=9$ & B & Q & & \\
\hline & S & C & & \\
\hline$(2+6) \times 1=8$ & & & & \\
\hline$(3-3) \times 2=0$ & B & R & & \\
\hline & B & P & & \\
\hline$(7-2) \times 1=2$ & & & & \\
\hline$(4-2) \times 4=8$ & S & T & & \\
\hline
\end{tabular}

Set 1

\begin{tabular}{|l|c|c|c|c|}
\hline HITUNG & B/S & HURUF & CHECK & TOTAL \\
\hline$(4+8) \times 1=11$ & S & B & & \\
\hline$(7-6) \times 2=2$ & B & G & & \\
\hline & & & & \\
\hline$(3-2) \times 1=4$ & S & D & & \\
\hline$(1+1) \times 3=4$ & S & F & & \\
\hline & & & & \\
\hline$(2+2) \times 2=8$ & B & H & & \\
\hline$(1-1) \times 4=5$ & S & K & & \\
\hline
\end{tabular}


Set 2

\begin{tabular}{|l|c|c|c|c|}
\hline HITUNG & B/S & HURUF & CHECK & TOTAL \\
\hline$(9-5) \times 2=8$ & B & A & & \\
\hline$(4-3) \times 3=3$ & B & M & & \\
\hline$(2-1) \times 2=5$ & S & I & & \\
\hline & & & & \\
\hline$(5-4) \times 4=4$ & B & R & & \\
\hline$(5-2) \times 2=3$ & S & E & & \\
\hline$(4-1) \times 1=6$ & S & Z & & \\
\hline & & & & \\
\hline$(4-3) \times 5=5$ & B & Q & & \\
\hline$(6-1) \times 1=6$ & S & P & & \\
\hline$(2+3) \times 1=5$ & B & K & & \\
\hline
\end{tabular}

Set 3

\begin{tabular}{|l|c|c|l|l|}
\hline HITUNG & B/S & HURUF & CHECK & TOTAL \\
\hline$(7-3) \times 2=8$ & B & W & & \\
\hline$(7-2) \times 1=5$ & B & J & & \\
\hline$(3+5) \times 1=3$ & S & H & & \\
\hline$(9+2) \times 1=9$ & S & L & & \\
\hline & & & & \\
\hline$(1+1) \times 2=4$ & B & P & & \\
\hline$(4-3) \times 3=6$ & S & U & & \\
\hline$(7-4) \times 1=3$ & B & M & & \\
\hline$(8-6) \times 2=1$ & S & V & & \\
\hline & & & & \\
\hline$(2-2) \times 5=3$ & S & N & & \\
\hline$(3-1) \times 2=5$ & S & J & & \\
\hline$(4+1) \times 1=5$ & B & Y & & \\
\hline$(3-3) \times 5=1$ & S & O & & \\
\hline
\end{tabular}




\section{Lampiran 2}

\section{Physical Activity Questionnaire for Adolescent (PAQ-A)}

Nomor Responden

Tanggal

Jenis Kelamin

:

$: \bar{M} / \mathrm{F}$

\section{Petunjuk:}

- Pilihlah jawaban yang menurut adik paling benar.

- Semua pernyataan harus dijawab dengan jujur.

- Pilih salah satu jawaban dengan tanda silang (X)

1. Apakah adik melakukan beberapa olahraga dibawah ini selama seminggu ini? Jika "iya", berapa kali? Berikan tanda silang "X" pada jawaban yang sesuai.

\begin{tabular}{|l|l|l|l|l|l|}
\hline & Tidak Pernah & $1-2$ kali & $3-4$ kali & $5-6$ kali & $\begin{array}{c}\text { Lebih dari } 7 \\
\text { kali }\end{array}$ \\
\hline Bermain tali (lompat tali) & & & & & \\
\hline Futsal & & & & & \\
\hline Voli & & & & & \\
\hline Basket & & & & & \\
\hline Jalan & & & & \\
\hline Bersepeda & & & & \\
\hline Lari-lari / jogging & & & & \\
\hline Senam & & & & \\
\hline Berenang & & & & & \\
\hline Kasti & & & & \\
\hline Menari / balet & & & & \\
\hline Sepak bola & & & & & \\
\hline Badminton & & & & \\
\hline Sepak takraw & & & & \\
\hline Sepatu roda & & & & \\
\hline Tenis & & & & \\
\hline Tenis meja & & & & \\
\hline Silat / karate / taekwondo & & & & \\
\hline Lainnya... & & & & \\
\hline Lainnya... & & & & \\
\hline
\end{tabular}


2. Selama seminggu ini, selama pelajaran olahraga pernahkah adik bersikap aktif dalam melakukan olahraga?
a. Tidak ikut pelajaran olahraga
b. Jarang aktif
c. Kadang-kadang aktif
d. Sering aktif
e. Selalu aktif

3. Selama seminggu ini, apa yang sering adik lakukan ketika waktu istirahat di sekolah?
a. Duduk-duduk (mengobrol, membaca, me- ngerjakan tugas)
b. Berdiri di sekitar
c. Jalan-jalan berkeliling
d. Kadang lari-lari dan bermain
e. Sering berlari-lari dan bermain

4. Selama seminggu ini, apa yang sering adik lakukan ketika jam makan siang di sekolah selain makan?
a. Duduk-duduk (mengobrol, membaca, me- ngerjakan tugas)

b. Berdiri di sekitar

c. Jalan-jalan berkeliling

d. Kadang lari-lari dan bermain

e. Sering berlari-lari dan bermain

5. Selama seminggu ini, setelah pulang sekolah pernahkah adik melakukan olahraga (sepakbola, kejar-kejaran sesama teman, atau menari yang membuat berkeringat)?
a. Tidak pernah
b. 1 kali seminggu
c. 2-3 kali seminggu
d. 4-5 kali seminggu
e. 6-7 kali seminggu

6. Selama seminggu ini, pada sore hari pernahkah adik melakukan olahraga (sepakbola, kejarkejaran sesama teman, atau menari yang membuat berkeringat)?
a. Tidak pernah
b. 1 kali seminggu
c. 2-3 kali seminggu
d. 4-5 kali seminggu
e. 6-7 kali seminggu

7. Pada hari sabtu dan minggu kemarin, pernahkah adik melakukan olahraga (sepakbola, kejar- kejaran sesama teman, atau menari yang membuat berkeringat)?
a. Tidak pernah
b. 1 kali
c. 2-3 kali
d. 4-5 kali
e. Lebih dari 5 kali

8. Bacalah semua pernyataan di bawah ini. Pilih salah satu pernyataan yang menggambarkan dirimu!

a. Hampir seluruh waktu luang saya habiskan untuk bersantai.

b. Di waktu luang, saya kadang-kadang (1-2 kali seminggu) melakukan aktivitas seperti olahraga (lari-lari, sepakbola, bersepeda, dan lain-lain)

c. Di waktu luang, saya sering (3-4 kali seminggu) melakukan aktivitas seperti olahraga (larilari, sepakbola, bersepeda, dan lain-lain)

d. Di waktu luang, saya lebih sering (5-6 kali seminggu) melakukan aktivitas seperti olahraga (lari-lari, sepakbola, bersepeda, dan lain-lain)

e. Di waktu luang, saya sangat sering ( $>6$ kali seminggu) melakukan aktivitas seperti olahraga (lari-lari, sepakbola, bersepeda, dan lain-lain)

9. Kapan adik melakukan olahraga (seperti larilari, sepakbola, bersepeda, menari dan lain-lain). Berilah tanda silang "X" pada jawaban yang sesuai.

\begin{tabular}{|lccccc|}
\hline Hari & Tidak & $1-2$ & $3-4$ & $5-6$ & Lebih dari \\
& pernah & kali & kali & kali & 7 kali \\
Senin & a & b & c & d & e \\
Selasa & a & b & c & d & e \\
Rabu & a & b & c & d & e \\
Kamis & a & b & c & d & e \\
Jumat & a & b & c & d & e \\
Sabtu & a & b & c & d & e \\
Minggu & a & b & c & d & e \\
\hline
\end{tabular}

10. Apakah selama seminggu ini adik pernah sakit sehingga tidak bisa berangkat sekolah dan harus tiduran di kamar?
a. Ya
b. Tidak 